\title{
Production and characterization of polyhydroxybutyrate (PHB) produced by Bacillus sp. isolated from Egypt
}

\author{
Mohamed A. Hassan ${ }^{1 *}$, Elsayed K. Bakhiet ${ }^{2}$, Salah G. Ali ${ }^{2}$, Hussien R. Hussien ${ }^{2}$ \\ ${ }^{1}$ Protein Research Department, Genetic Engineering and Biotechnology Research Institute (GEBRI), City of Scientific Research and Technological \\ Applications (SRTA-City), New Borg El-Arab City, P.O. Box: 21934 Alexandria, Egypt. ${ }^{2}$ Botany and Microbiology Department, Faculty of Science, \\ Al-Azhar University, P.O. Box: 71524 Assiut, Egypt.
}

\begin{tabular}{l} 
ARTICLE INFO \\
\hline Article history: \\
Received on: 04/01/2016 \\
Revised on: 07/02/2016 \\
Accepted on: 26/02/2016 \\
Available online: 30/04/2016 \\
\hline Key words: \\
Biopolymer; PHB; Bacillus \\
sp.; Nile red dye; ${ }^{\text {H NMR. }}$
\end{tabular}

\begin{abstract}
Synthetic polymers are non-degradable and accumulated in the environment so, the efforts of scientists were forwarded to provide us with alternative environmentally biopolymers. Polyhydroxyalkanoates (PHAs) including polyhydroxybutyrate (PHB) are Group of the interesting biopolymers which have several medical applications such as drug delivery, suture, scaffold and heart valves. PHAs are biological macromolecules, thermoplastics, biodegradable and biocompatible. In this study, new bacterial isolates from Egypt were screened for their ability to produce PHB using Nile red dye. Out of 44 isolates, 19 bacterial isolates were selected according to strong of their fluorescence on mineral salt medium (MSM) agar plates supplemented with Nile red. The most potent strain was identified using biochemical tests as Bacillus sp. N-2. Production of PHB was carried out in limitation of nitrogen source using a minimal salt medium (MSM) supplemented with an excess of glucose as sole carbon source. PHB was accumulated in relation to cell dry weight about 20\% (PHB/CDW). The obtained biopolymer was purified and analyzed using NMR, FT-IR, TGA and DSC thus; it was highly pure and identified as PHB. Optimization of PHB production from cheap sources appears to be a realistic goal in the future for reducing the costs and obtaining high yield.
\end{abstract}

\section{INTRODUCTION}

The great use of petroleum plastics is the major cause of environmental pollution because the plastics need years for degrading to soluble monomers and many types of toxic gases are drawback during the decomposition process (Anderson and Dawes, 1990; Suriyamongkol et al., 2007; Campos et al., 2014). Consequently, there have been developing open and scientific concerns in regards to the utilization and development of biopolymer as a biologically valuable different option for plastics (Muller et al., 2001; Amara et al., 2011). Among the biodegradable polymers, polyhydroxyalkanoates (PHA) which fit

* Corresponding Author

Mohamed A. Hassan, Protein Research Department, Genetic

Engineering and Biotechnology Research Institute (GEBRI), City of

Scientific Research and Technological Applications (SRTA-City), New

Borg El-Arab City, P.O. Box: 21934 Alexandria, Egypt.

Email: m_adelmicro[at]yahoo.com in with the gathering of polyesters has gotten vigorous consideration due to their features as biodegradable thermoplastics (Albuquerque et al., 2007). PHAs are divided into three groups: short chain length, medium chain length and long chain length PHA (scl-PHAs, mcl-PHAs and lcl-PHAs respectively). These categories were classified according to the number of carbon atoms, where scl-PHA of 3-5 carbon atoms, mcl-PHA of 6-14 carbon atoms and lcl-PHA of more than 15 carbon atoms (Madison and Huisman, 1999). Many microorganisms have been discovered that be able to produce PHAs as insoluble granules intracellularely under stress conditions, in presence of excess carbon source and limited concentration of nitrogen, phosphorus or oxygen (Anderson and Dawes, 1990; Pan et al., 2012). Several microorganisms have been utilized to produce different types of PHAs including Gram positive like Bacillus megaterium, Bacillus subtilis and Corynebacterium glutamicum, Gram negative bacteria like group of Pseudomonas and Alcaligenes eutrophus and cyanobacteria such as Nostoc muscorum, Synechococcus sp. and 
Spirulina platensis (Jo et al., 2007; Hassan et al., 2010; López et al., 2012; Sharma and Mallick, 2005; Jau et al., 2005). Based on microorganisms, the structure, physico-chemical properties, monomer composition, mass and size of PHAs differ considerably (Ha and Cho, 2002).

The most surely understood structure of PHAs is poly-3hydroxybutyrate (PHB), a scl-PHA which can be synthesized by a wide range of microorganisms but the main interest group is Bacillus strains due to lack toxicity of the extracted PHB (Gahlawat et al., 2012; Singh et al., 2009). Amara et al. (2013) reported the interests of scientists to produce biopolymers and biotechnological products with the safe method to be suitable for different applications.

In addition to the biocompatibility of PHAs, they have properties like that of polypropylene, biodegradability, highly hydrophobic and thermoplastic, with high crystallinity, high melting temperature, and good resistance to organic solvents (Sudesh et al., 2000). PHAs are of biological origin; they could be completely broken down in to water and carbon dioxide by microorganisms found in a wide range of environments (Byrom, 1987). Therefore, they have various medical applications including drug delivery, sutures and embed materials general (Deng et al., 2003). In order to apply the biotechnological products, they should be examined on cell culture and animal model as shown by Abdou and Hassan (2014). The objective of the present study was to isolate a new bacterial isolate has the ability to produce PHB in a safe method for applying in medical applications. The PHB produced by Bacillus sp. was identified using $1 \mathrm{H}$ nuclear magnetic resonance (1HNMR) and Fourier transform infrared (FT-IR). In addition, the physical properties of PHB were investigated through Thermogravimetric analysis (TGA) and Differential scanning calorimetric (DSC) to select the potential applications in the future.

\section{MATERIAL AND METHODS}

\section{Isolation of bacterial strains}

Soil samples were collected from different sites of Alexandria and Assiut Governorates, Egypt. The samples were collected from depth $(7-10 \mathrm{~cm})$ of the soil surface in sterilized falcon tubes and transferred immediately to a microbiology lab.

The samples were suspended in sterilized saline solution $(0.85 \%, \mathrm{w} / \mathrm{v})$ and streaked on nutrient agar medium contained 5.0 $\mathrm{g} / \mathrm{l}$ peptone, $3.0 \mathrm{~g} / \mathrm{l}$ beef extract, $5.0 \mathrm{~g} / \mathrm{l}$ sodium chloride and $15 \mathrm{~g} / \mathrm{l}$ agar; $\mathrm{pH}$ was adjusted at $7.2 \pm 0.2$ ). The plates were incubated at $37^{\circ} \mathrm{C}$ for $48 \mathrm{hrs}$ then; the different colonies were picked and subjected to series steps for obtaining purified strain (Abol Fotouh et al., 2016).

\section{Screening of PHB producing bacteria Nile red staining}

The screening method which was described by Spiekermann et al. (1999) was conducted for detecting the ability of bacterial isolates to accumulate PHAs. The isolated strains were grown on mineral salt medium (MSM) which was prepared according to Schlegel et al. (1961) and supplemented with $20 \mathrm{~g} / \mathrm{l}$ glucose as carbon source (Aramvash et al., 2015). MSM consisted of $9.0 \mathrm{~g} / 1 \mathrm{Na}_{2} \mathrm{HPO}_{4 \cdot 2} \mathrm{H}_{2} \mathrm{O}, 1.5 \mathrm{~g} / 1 \mathrm{KH}_{2} \mathrm{PO}_{4}, 0.4 \mathrm{~g} / 1 \mathrm{NH}_{4} \mathrm{Cl}, 0.2 \mathrm{~g} / \mathrm{l}$ $\mathrm{MgSO}_{4} \cdot 7 \mathrm{H}_{2} \mathrm{O}, 0.02 \mathrm{~g} / 1 \mathrm{CaCl}_{2} .2 \mathrm{H}_{2} \mathrm{O}, 1.2 \mathrm{mg} / \mathrm{l} \mathrm{Fe}(\mathrm{III}) \mathrm{NH}_{4}$ - citrate, $0.1 \mathrm{ml} / \mathrm{l}$ Trace elements solution 6 and $15 \mathrm{~g} / \mathrm{l}$ agar. The trace element solution comprised of (per liter of distilled water): $10 \mathrm{mg} / \mathrm{l}$ $\mathrm{ZnSO}_{4} .7 \mathrm{H}_{2} \mathrm{O}, 3 \mathrm{mg} / \mathrm{l} \mathrm{MnCl}_{2} \cdot 4 \mathrm{H}_{2} \mathrm{O}, 30 \mathrm{mg} / \mathrm{l} \mathrm{H}_{3} \mathrm{BO}_{3}, 20 \mathrm{mg} / \mathrm{l}$ $\mathrm{CoCl}_{2} \cdot 6 \mathrm{H}_{2} \mathrm{O}, 1 \mathrm{mg} / \mathrm{CuCl}_{2} \cdot 2 \mathrm{H}_{2} \mathrm{O}, 2 \mathrm{mg} / 1 \mathrm{NiCl}_{2} \cdot 6 \mathrm{H}_{2} \mathrm{O}$ and $3 \mathrm{mg} / \mathrm{l}$ $\mathrm{Na}_{2} \mathrm{MoO}_{4} \cdot 2 \mathrm{H}_{2} \mathrm{O}$ and it was sterilized with $0.22 \mu \mathrm{m}$ sterilized filter system.

The glucose was autoclaved separately, allowed to cooling down to $55^{\circ} \mathrm{C}$ and it was added in a suitable final concentration to the prepared medium. In addition, MSM was supplemented with a solution of $0.25 \mathrm{mg}$ Nile red in DMSO to give a final concentration of $0.5 \mu \mathrm{g}$ dye (ml medium) $)^{-1}$. The bacterial isolates were streaked and incubated at $37^{\circ} \mathrm{C}$ for 5 days. The agar plates were exposed to ultraviolet light $(312 \mathrm{~nm})$ using a gel documentation system (Model DI-C1-220, Major science Co., Taiwan) to investigate the accumulation of PHAs in positive isolates.

\section{Strain identification \\ Morphological and biochemical test}

The colony characteristics including the pigment of the potent bacterial isolate were observed. The ability of the bacterial isolate $(\mathrm{N}-2)$ to hydrolyze starch, gelatin, casein and cellulose was investigated. Other biochemical tests like methyl red, indole production test, Vogues Proskauer test, motility, catalase, citrate utilization were conducted in the defined medium using specific reagents.

The sugar fermentation was studied by inoculating the bacterial isolate in the defined medium including various sugars (xylose, mannose, sucrose, sorbitol, galactose, rhaffinose, glucose, fructose, ribose, lactose and rhamnose). The morphological and physiological characteristics of the bacterial isolates were compared with the data from Bergey's Manual of Determinative Bacteriology (Holt et al., 1994).

\section{Production of PHB by Bacillus sp. N-2}

Bacillus sp. N-2 was first grown on nutrient broth medium and incubated at $37^{\circ} \mathrm{C}$ and $150 \mathrm{rpm}$ for $24 \mathrm{hrs}$ to obtain a large amount of cells. Then, $2 \%(\mathrm{v} / \mathrm{v})$ of the liquid culture was transferred to MSM with $2 \%$ glucose as the sole carbon source and incubated at $37^{\circ} \mathrm{C}$ and $150 \mathrm{rpm}$ for 5 days in shaking incubator (Model Innova ${ }^{\mathrm{Tm}} \mathrm{J}-25$, New Brunswick scientific, USA).

\section{Extraction and purification of PHB}

The purification of PHB was performed according to the method which was optimized by Hassan et al. (2010). Briefly, the bacterial cells were collected by centrifugation of culture at 11,000 rpm for $15 \mathrm{~min}$.

The cells were washed twice in saline solution and dried overnight in an oven at $50^{\circ} \mathrm{C}$ for $24 \mathrm{hrs}$. The dried cells were 
treated with $10 \%$ SDS at $100^{\circ} \mathrm{C}$ for $20 \mathrm{~min}$. After centrifugation, the pellets were washed, dried, and extracted with chloroform at $60^{\circ} \mathrm{C}$ for $1 \mathrm{hr}$.

The non-PHB cell matter was removed by filtration using filter paper (what man no. 1) and the dissolved PHB was precipitated from chloroform by addition of 4-6 volume of ice cold methanol. The obtained PHB was left in -20 for $30 \mathrm{~min}$ and centrifuged at $11,000 \mathrm{rpm}$ for $15 \mathrm{~min}$ to obtain a high yield of biopolymer. The obtained biopolymer was dried overnight at $60^{\circ} \mathrm{C}$.

\section{Characterization of PHB}

\section{NMR of the purified PHB from Bacillus sp. N-2}

${ }^{1} \mathrm{H}$ NMR spectra was carried out by dissolving the purified $\mathrm{PHB}$ in deuterochloroform $\left(\mathrm{CDCl}_{3}\right)$ at a concentration of $10 \mathrm{mg} / \mathrm{ml}$ and analyzed on a Bruker Avance II 500 spectrometer.

\section{FT-IR analysis of PHB from Bacillus sp. $\mathrm{N}-2$}

FT-IR analysis of PHB produced by Bacillus sp. N-2 was investigated by FT-IR (Model 8400 S, Shimadzu, Japan). Sample about $5 \mathrm{mg}$ was mixed well with $\mathrm{KBr}$, and the absorbance of sample was scanned from $400-4000 \mathrm{~cm}^{-1}$ following the method which was described by Tamer et al. (2015).

\section{TGA of PHB produced by Bacillus sp. $\mathrm{N}-2$}

Thermal analysis of Purified PHB sample was performed using TGA instrument (Model 50/50H, Shimadzu, Japan). The analysis method was carried out with $5 \mathrm{mg}$ of biopolymer at a temperature range $\left(27-450^{\circ} \mathrm{C}\right)$ under nitrogen atmosphere at a heating rate of $10^{\circ} \mathrm{C} \mathrm{min}^{-1}$.

\section{DSC analysis of PHB produced by Bacillus sp. $\mathrm{N}-2$}

The Purified PHB was run in DSC using DSC instrument (Model 60A, Shimadzu, Japan) at a temperature range from -20 to $450^{\circ} \mathrm{C}$ with the heating rate of $10^{\circ} \mathrm{C}$ min $^{-1}$. Melting temperature was compared with standard PHB (Sigma, USA) from previous literature (Corre et al., 2012).

\section{RESULTS AND DISCUSSION}

\section{Isolation and screening of a bacterium producing PHA}

After incubation of nutrient agar plates medium at $37^{\circ} \mathrm{C}$ for $48 \mathrm{hrs}$, a total of 44 different bacterial colonies were picked up as pure colonies and maintained on nutrient agar slants for further experiments. Total 29 isolates were obtained from Alexandria Governorate while 15 isolates were isolated from Assiut governorates.

Different isolates obtained were streaked on plates contained MSM agar medium supplemented with glucose $(2 \%)$ and Nile red dye $(0.5 \mu \mathrm{g} / \mathrm{ml})$. The plates were observed under transilluminator for fluorescent colonies thus, 19 isolates revealed fluorescence under UV light. Amongst 19 bacterial isolates, the potent isolate was obtained from Assiut and named N-2 was selected based on maximum fluorescence as shown in figure 1. (Shrivastav et al., 2010).
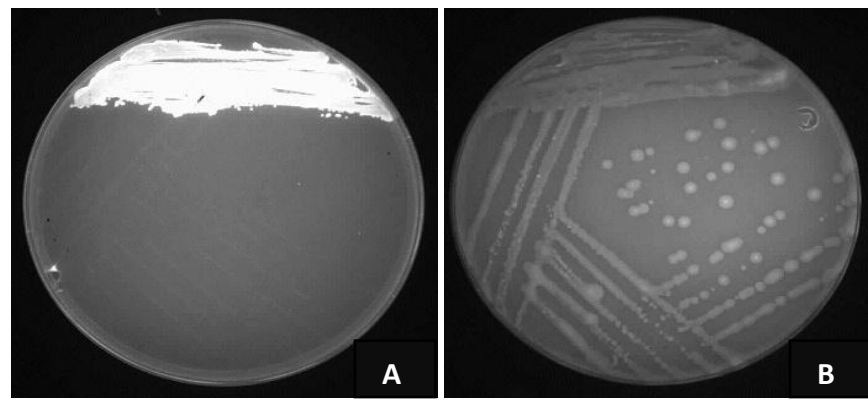

Fig. 1: Screening of bacterial isolates from soil using Nile red viable colony staining method. Figure $(1 \mathrm{~A})$ indicates to positive isolate which accumulates PHB and shows with fluorescence under UV light; Figure (1B) indicates to negative bacterial isolate.

\section{Strain identification}

The morphological characteristics of strain $\mathrm{N}-2$ were investigated. We found that strain N-2 is aerobic, Gram positive, motile, spore-forming, rod-shaped Bacillus. In addition, the biochemical features were examined and N-2 was able to ferment different sugars like glucose, galactose, sucrose, mannose, xylose, ribose, fructose, lactose, Sorbitol, Rhamnose and Rhaffinose.

Table 1: Morphological and biochemical features of Bacillus sp. N-2.

\begin{tabular}{|c|c|}
\hline Morphological and biochemical tests & Bacillus sp. N-2 \\
\hline \multicolumn{2}{|l|}{ Morphological: } \\
\hline Shape & Rods \\
\hline Gram stain & G+ve \\
\hline Motility & Motile \\
\hline spore formation & + ve \\
\hline \multicolumn{2}{|l|}{ Growth at different concentrations of $\mathrm{NaCl}$ : } \\
\hline $3 \%$ & +ve \\
\hline $5 \%$ & + ve \\
\hline $10 \%$ & +ve \\
\hline \multicolumn{2}{|l|}{ Biochemical tests: } \\
\hline Catalase & +ve \\
\hline Voges- Proskauer & + ve \\
\hline Inodol production & -ve \\
\hline Citrate utilization & -ve \\
\hline $\mathrm{H}_{2} \mathrm{~S}$ production & -ve \\
\hline \multicolumn{2}{|l|}{ Hydrolysis of: } \\
\hline Casein & + ve \\
\hline Gelatin & + ve \\
\hline Cellulose & + ve \\
\hline Starch & -ve \\
\hline \multicolumn{2}{|l|}{ Carbohydrates fermentation: } \\
\hline Glucose & $+v e$ \\
\hline Galactose & +ve \\
\hline Sucrose & +ve \\
\hline Mannose & +ve \\
\hline Xylose & +ve \\
\hline Ribose & +ve \\
\hline Fructose & $+v e$ \\
\hline Sorbitol & +ve \\
\hline Lactose & -ve \\
\hline Rhamnose & +ve \\
\hline Rhaffinose & +ve \\
\hline
\end{tabular}

The culture exhibited no growth on starch and negative for $\mathrm{H}_{2} \mathrm{~S}$ production, while $\mathrm{N}-2$ showed the ability to utilize casein, gelatin and cellulose. Moreover, the strain was positive for Voges Proskauer test, methyl red and catalase as well as, negative for 
citrate utilization and indol production. The strain showed that it was able to grow on different concentration of $\mathrm{NaCl}(3 \%, 5 \%$ and $10 \%)$.

The morphological and physiological characteristics of $\mathrm{N}-2$ were summarized as shown in table 1 . The morphological and biochemical characteristics indicated that the bacterium $\mathrm{N}-2$ belonged to Bacillus sp. group according to Bergey's Manual of Determinative Bacteriology (Holt et al., 1994). However, the most results are similar to those which were obtained by Hassan et al. (2013) concerning the identification of Bacillus sp. strains so; it was named Bacillus sp. N-2.

\section{Production and extraction of PHB}

PHB was synthesized by Bacillus sp. N-2 as described above using accessing of carbon source ( $2 \%$ of glucose) and minimal concentration of nitrogen source $\left(0.4 \mathrm{~g} / 1 \mathrm{NH}_{4} \mathrm{Cl}\right)$. After incubation for 5 days, the cells were harvested and the cell dry weight was $0.85 \mathrm{~g} / \mathrm{l}$. The PHB that accumulated in the cells was extracted using SDS and chloroform.

The amount of extracted PHB was recorded $(0.17 \mathrm{~g} / \mathrm{l})$ and calculated in relation to cell dry weight as $20 \% \mathrm{CDW}$. Previous articles reported that the accumulated PHB in the cells from B. megaterium and Massilia sp. UMI-21 using glucose before optimizing the culture conditions were $21.7 \%$ and 2.4\% CDW respectively (Dhangdhariya et al., 2015; Han et al., 2014).

\section{Characterization of PHB}

\section{NMR of PHB from Bacillus sp. $\mathrm{N}-2$}

The ${ }^{1} \mathrm{H}$ NMR of PHB from Bacillus sp. N-2 was carried out as shown in figure 2. The resonance of $\mathrm{PHB}$ at $1.6 \mathrm{ppm}$ corresponds to the methyl group $\left(\mathrm{CH}_{3}\right)$, while the signal at $2.4 \mathrm{ppm}$ is attributed to a methylene group $\left(\mathrm{CH}_{2}\right)$. The signal at $5.2 \mathrm{ppm}$ is indicated to methane group $(\mathrm{CH})$. Consequently, the obtained results are consistent with the previous report (Han et al., 2014).

\section{FT-IR of PHB from Bacillus sp. N-2}

Figure 3 demonstrates FT-IR spectrum of the purified PHB. The peak at $1721 \mathrm{~cm}^{-1}$ indicates to ester carbonyl group of PHB. Moreover, the peak at $1280 \mathrm{~cm}^{-1}$ is due to the $-\mathrm{CH}$ group in the biopolymer (Bayari and Severcan, 2005). The peak at 2935 $\mathrm{cm}^{-1}$ corresponds to the stretching and deformation vibrations of the $\mathrm{O}-\mathrm{H}$ groups. The presence of the peak at $2983 \mathrm{~cm}^{-1}$ may be due to the $\mathrm{C}-\mathrm{H}$...O hydrogen bond. The specific peak at wave numbers $3442 \mathrm{~cm}^{-1}$ attributes to the terminal $\mathrm{O}-\mathrm{H}$ bonding or water adsorption on the PHB (López et al., 2012). The FT-IR spectrum is very closer to the FT-IR spectra of PHB extracted from Bacillus shackletonii K5, B. megaterium and commercial PHB (Liu et al., 2014; Dhangdhariya et al., 2015).

\section{TGA analysis of PHB from Bacillus sp. $\mathrm{N}-2$}

TGA of purified biopolymer from Bacillus sp. N-2 strain was performed to detect the thermal stability of PHB. Figure 4 shows that degradation of PHB was done in three stages and the melting point of the polymer was started at $134^{\circ} \mathrm{C}$, but only $0.8 \%$ of the total mass was lost. At $237^{\circ} \mathrm{C}$, The polymer was lost about $1.6 \%$ of total mass in second stage. It should be noted that PHB was almost degraded at $275^{\circ} \mathrm{C}$, with maximized degradation occurring at $320^{\circ} \mathrm{C}$ and in this stage about $96 \%$ of polymer was lost. Dhangdhariya et al.,(2015) reported that the PHA was degraded in two stages and completely degrade at $300^{\circ} \mathrm{C}$, while our results revealed that the PHB was decomposed in three stages and resist till $320^{\circ} \mathrm{C}$. On the other hand, produced PHB from Bacillus shackletonii K5 was decomposed completely in two stages and reach to $280^{\circ} \mathrm{C}$ as maximum temperature (Liu et al., 2014).

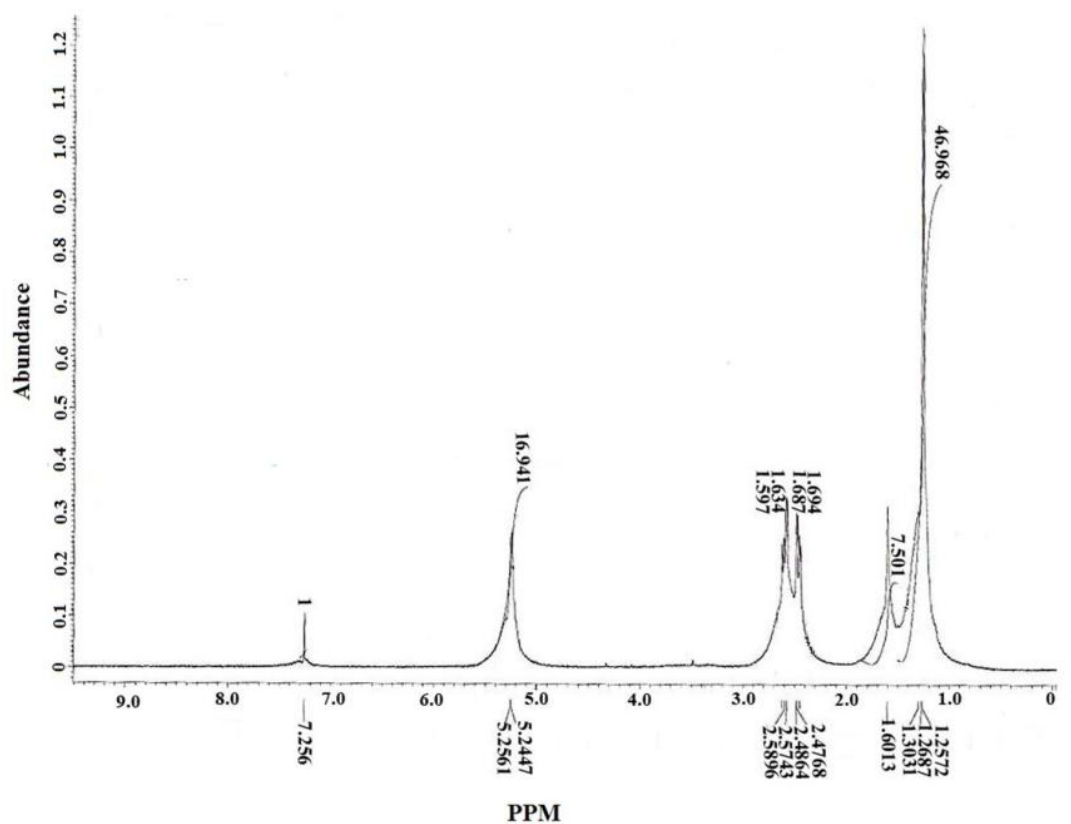

Fig. 2: ${ }^{1} \mathrm{H}$ NMR signals of purified PHB produced by Bacillus sp. N-2 using glucose as carbon source. 


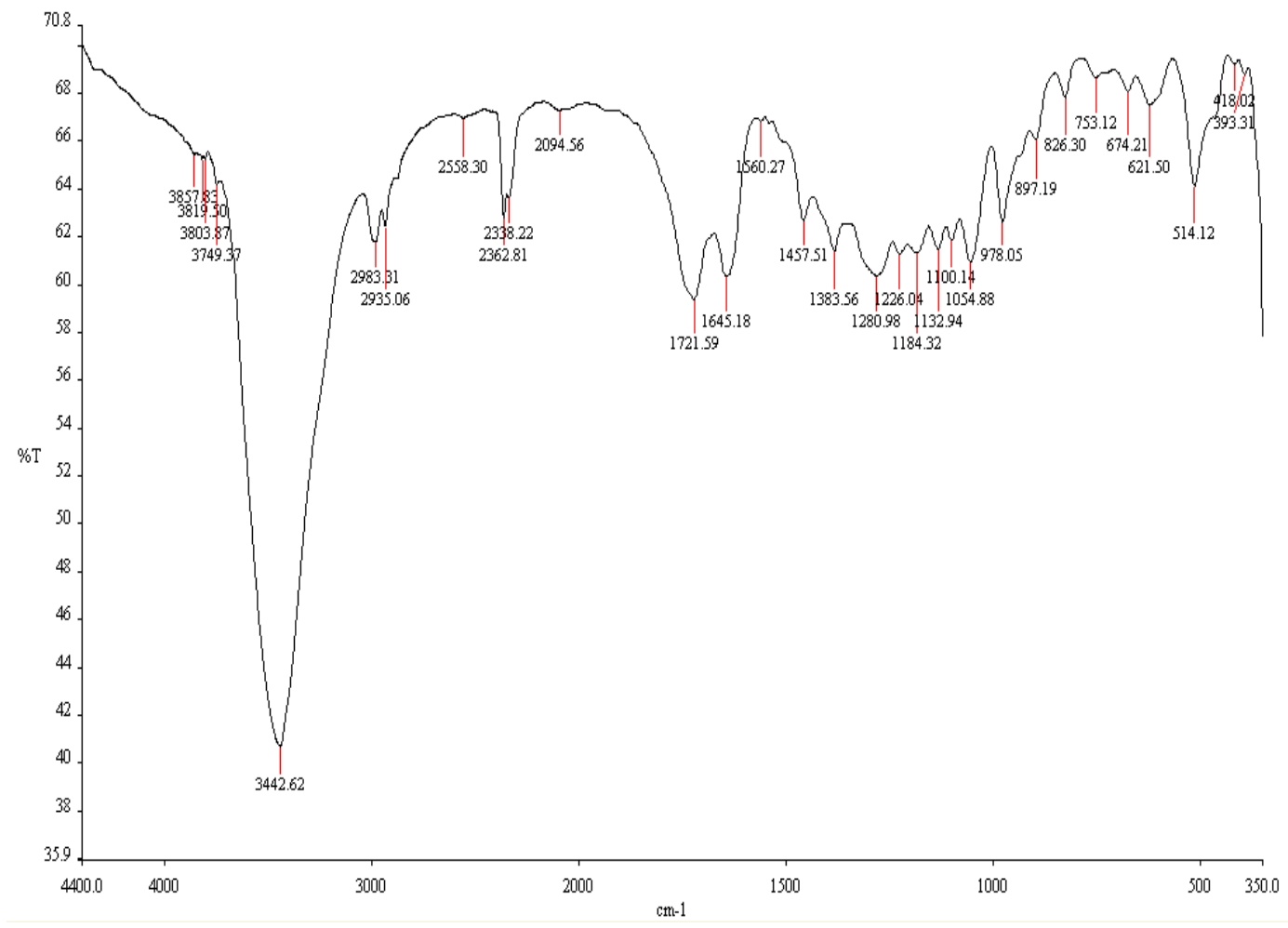

Fig. 3: FT-IR spectrum of purified PHB produced by Bacillus sp. N-2 using glucose as carbon source.

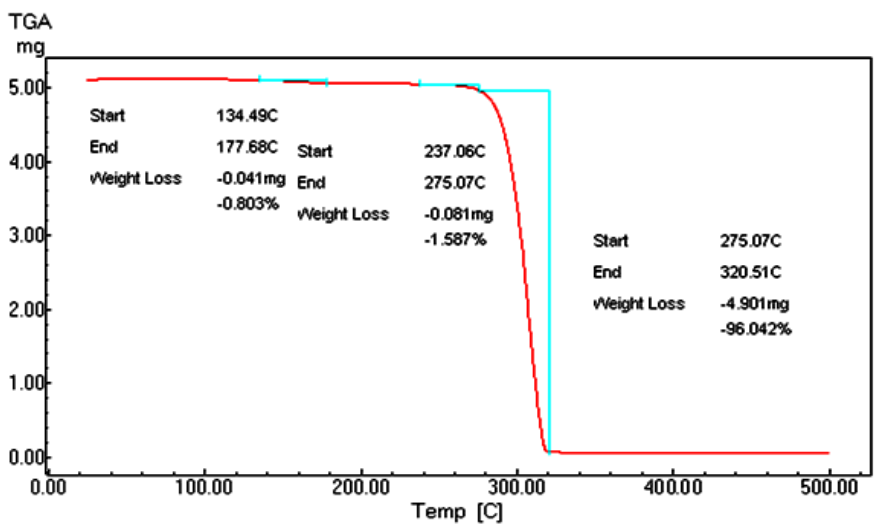

Fig. 4: TGA analysis of purified PHB produced by Bacillus sp. N-2 using glucose as carbon source.

\section{DSC analysis of PHB from Bacillus sp. $\mathrm{N}-2$}

DSC analysis was conducted to investigate the melting temperature, glass transition temperature and heat associated in melting of PHB. The $\mathrm{T}_{\mathrm{m}}$ of $\mathrm{PHB}$ was $175.9^{\circ} \mathrm{C}$ and the heat associated with melting was $57.84 \mathrm{~J} / \mathrm{g}$ for the first peak. The second peak showed at $298^{\circ} \mathrm{C}$ in correlated with heat about 526.3 $\mathrm{J} / \mathrm{g}$ (figure 5). These results are proved by the previous literature (Vizcaino-Caston et al., 2015).

\section{CONCLUSION}

In the current study, different bacterial isolates were obtained from Egypt and screened for PHB production using glucose as carbon source and Nile red as detector. A new bacterial

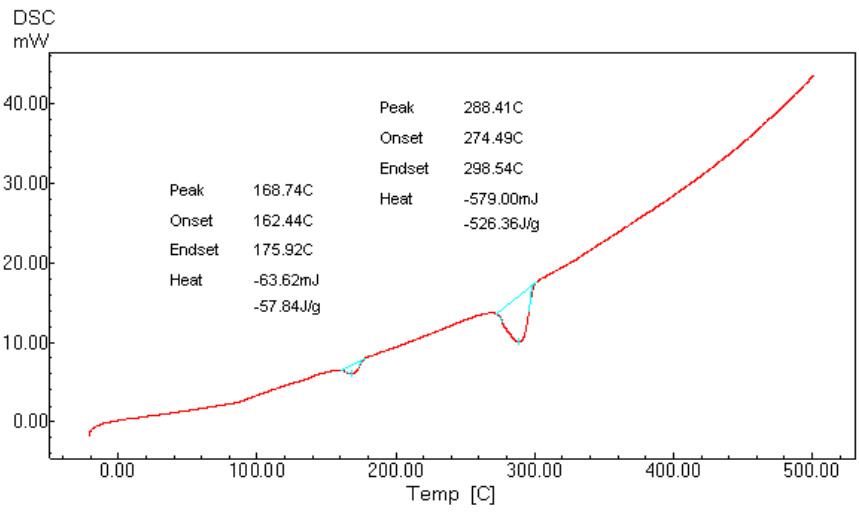

Fig. 5: DSC analysis of purified PHB produced by Bacillus sp. N-2 using glucose as carbon source.

isolate (Bacillus sp. N-2) was selected, and it was successfully characterized and identified using morphological and biochemical characters. However, it had the ability to produce PHB with amount about $20 \%$ of cell dry weight. The produced PHB was characterized using ${ }^{1} \mathrm{H}$ NMR, FTIR, TGA and DSC. In addition, the results demonstrated that the biopolymer is PHB and highly purified. The future approaches will be concerned with optimization of culture conditions and utilization of houses and industry wastes as a carbon source for PHB production using Bacillus sp. N-2.

\section{CONFLICT OF INTEREST}

The authors have no conflict of interest to declare. 


\section{REFERENCES}

Abdou H, Hassan MA. Protective Role of Omega-3 polyunsaturated Fatty Acid Against Lead Acetate-induced Toxicity in Liver and Kidney of Female Rats. Biomed Research International Journal, 2014; Article ID 435857: 11 pages, doi.org/10.1155/2014/435857.

Abol Fotouh DM, Bayoumi RA, Hassan MA. Production of thermoalkaliphilic lipase from GeoBacillus thermoleovorans DA2 and application in leather industry. Enzyme Research, 2016; Article ID 9034364: 9 pages, http://dx.doi.org/10.1155/2016/9034364.

Albuquerque M, Eiroa M, Torres C, Nunes B, Reis M. Strategies for the development of a side stream process for polyhydroxyalkanoate (PHA) production from sugar cane molasses. Journal of Biotechnology, 2007; 130(4): 411-421.

Amara AA, Hassan MA, Abulhamd, AT, Haroun, BM. Algs genes: $\mathrm{H}_{2} \mathrm{O}_{2}$ map their viability and validity in Psuedomonas aeruginosa. International Journal of Biotechnology \& biochemistry, 2011; 7: 321-330.

Amara AA, Hassan MA, Abulhamd AT, Haroun BM. Nonmucoid $P$. aeruginosa aiming to safe production of protease and lipase. International Science and Investigation Journal, 2013; 2: 103-113.

Anderson AJ, Dawes EA. Occurrence, metabolism, metabolic role, and industrial uses of bacterial polyhydroxyalkanoates. Microbiological Reviews, 1990; 54(4): 450-472.

Aramvash A, Shahabi ZA, Aghjeh SD, Ghafari MD. Statistical physical and nutrient optimization of bioplastic polyhydroxybutyrate production by Cupriavidus necator. International Journal of Environmental Science and Technology, 2015; 12: 2307-2316.

Bayari S, Severcan F. FT-IR study of biodegradable biopolymers: $\mathrm{P}(3 \mathrm{HB}), \mathrm{P}(3 \mathrm{HB}-c o-4 \mathrm{HB})$ and $\mathrm{P}(3 \mathrm{HB}-c o-3 \mathrm{HV})$. Journal of Molecular Structure, 2005; 744: 529-534.

Campos MI, Figueiredo TVB, Sausa LS, Druzian JI. The influence of crude glycerin and nitrogen concentrations on the production of PHA by Cupriavidus necator using a response surface methodology and its characterizations. Industrial Crops and Products, 2014; 52: 338-346.

Corre YM, Bruzaud S, Audic JL, Grohens Y. Morphology and functional properties of commercial polyhydroxyalkanoates: a comprehensive and comparative study. Polymer Testing, 2012; 31: 226235 .

Dhangdhariya JH, Dubey S, Trivedi HB, Pancha I, Bhatt JK, Dave BP, Mishra S. Polyhydroxyalkanoate from marine Bacillus megaterium using CSMCRI's Dry Sea Mix as a novel growth medium. International Journal of Biological Macromolecules, 2015; 76: 254-261.

Gahlawat G, Sengupta B, Srivastava AK. Enhanced production of poly(3-hydroxybutyrate) in a novel airlift reactor with in situ cell retention using Azohydromonas australica. Journal of Industrial Microbiology \& Biotechnology, 2012; 39(9): 1377-1384.

Ha CS, Cho WJ. Miscibility, properties, and biodegradability of microbial polyester containing blends. Progress in Polymer Science, 2002; 27: 759-809.

Han X, Satoh Y, Kuriki Y, Seino T, Fujita S, Suda T, Kobayashi T, Tajima K. Polyhydroxyalkanoate production by a novel bacterium Massilia sp. UMI-21 isolated from seaweed, and molecular cloning of its polyhydroxyalkanoate synthase gene. Journal of Bioscience and Bioengineering, 2014; 118(5): 514-519.

Hassan MA, Amara AA, Abuelhamd AT, Haroun BM. Leucocytes show improvement growth on PHA polymer surface. Pakistan Journal of Pharmaceutical Science, 2010; 23: 332-336.

Hassan MA, Haroun BM, Amara AA, Serour EA. Production and characterization of keratinolytic protease from new wool-degrading Bacillus species isolated from Egyptian ecosystem. Biomed Research International Journal, 2013; Article ID 175012, 14 pages. doi.org/10.1155/2013/175012.

Holt JG, Krieg NR, Sneath PHA, Staley JT, Williams ST. 1994. Bergey's Manual of Determinative Bacteriology, Williams \&Wilkins, Baltimore, Md, USA.

Jau MH, Yew SP, Toh PSY, Chong SCA, Chu WL, Phang SM, Najimudin N, Sudesh K. Biosynthesis and mobilization of poly (3hydroxybutyrate $)[\mathrm{P}(3 \mathrm{HB})]$ by Spirulina platensis. International journal of biological macromolecules, 2005; 36: 144-151.
Jo SJ, Matsumoto $\mathrm{K}$, Leong $\mathrm{CR}$, Ooi $\mathrm{T}$, Taguchi $\mathrm{S}$. Improvement of poly(3-hydroxybutyrate) $[\mathrm{P}(3 \mathrm{HB})]$ production in Corynebacterium glutamicum by codon optimization, point mutation and gene dosage of $\mathrm{P}(3 \mathrm{HB})$ biosynthetic genes. Journal of Bioscience and Bioengineering, 2007; 104(6): 457-463.

Liu Y, Huang S, Zhang Y, Xu F. Isolation and characterization of a thermophilic Bacillus shackletonii $\mathrm{K} 5$ from a biotrickling filter for the production of polyhydroxybutyrate. Journal of environmental sciences, 2014; 26: 1453 - 1462 .

López JA, Naranjo JM, Higuita JC, Cubitto MA, Cardona CA, Villar MA. Biosynthesis of PHB from a new isolated Bacillus megaterium strain: outlook on future developments with endospore forming bacteria. Biotechnology and Bioprocess Engineering, 2012; 17(2): 250-258.

Madison LL, Huisman GW. Metabolic engineering of poly(3hydroxyalkanoates): from DNA to plastic. Microbiology and Molecular Biology Reviews, 1999; 63(1): 21-53.

Muller RJ, Kleeberg I, Deckwer WD. Biodegradation of polyesters containing aromatic constituents. Journal of Biotechnology, 2001; 86: 87-95

Pan WY, Perrotta JA, Stipanovic AJ, Nomura CT, Nakas JP. Production of polyhydroxyalkanoates by Burkholderia cepacia ATCC 17759 using a detoxified sugar maple hemicellulosic hydrolysate. Journal of Industrial Microbiology \& Biotechnology, 2012; 39(3): 459-469.

Schlegel HG, Kaltwasser H, Gottschalk G. A submerged culture hydrogen oxidizing bacteria: growth physiological studies. Archives of Microbiology, 1961; 38: 209-222.

Sharma L Mallick N. Enhancement of poly-betahydroxybutyrate accumulation in Nostoc muscorum under mixotrophy, chemoheterotrophy and limitations of gas-exchange. Biotechnology Letters, 2005; 27: 59-62.

Shrivastava A, Mishraa SK, Shethiab B, Panchab I, Jain D, Mishraa S. Isolation of promising bacterial strains from soil and marine environment for polyhydroxyalkanoates (PHAs) production utilizing Jatropha biodiesel byproduct. International Journal of Biological Macromolecules, 2010; 47: 283-287.

Singh M, Patel SKS, Kalia VC. Bacillus subtilis as potential producer for polyhydroxyalkanoates. Microbial Cell Factories, 2009; 8: $38-49$.

Spiekermann P, Rehm BHA, Rainer K, Dirk B, Steinbüchel A. A sensitive, viable-colony staining method using Nile red for direct screening of bacteria that accumulate polyhydroxyalkanoic acids and other lipid storage compounds. Archives of Microbiology, 1999; 171: 73-80.

Sudesh K, Abe H, Doi Y. Synthesis, structure and properties of polyhydroxyalkanoates: biological polyesters. Progress in Polymer Science, 2000; 25: 1503-1555.

Suriyamongkol P, Randall W, Suresh N, Maurice M, Saleh S. Biotechnological approaches for the production of polyhydroxyalkanoates in microorganisms and plants-a review. Biotechnology Advances, 2007; 25(2): 148-175.

Tamer TM, Omer AM, Hassan MA, Hassan ME, sabet Mm, Eldin MSM. Development of thermo-sensitive poly $\mathrm{N}$-isopropyl acrylamide grafted chitosan derivatives. Journal of Applied Pharmaceutical Science, 2015; 5(Supplement 3): 1- 6.

Vizcaino-Caston I, Kelly CA, Fitzgerald AVL, Leeke GA, Jenkins M, Overton TW. Development of a rapid method to isolate polyhydroxyalkanoates from bacteria for screening studies. Journal of Bioscience and Bioengineering, Technical note, 2015; 1 - 4.

\section{How to cite this article:}

Hassan MA, Bakhiet EK, Ali SG, Hussien HR. Production and characterization of polyhydroxybutyrate (PHB) produced by Bacillus sp. isolated from Egypt. J App Pharm Sci, 2016; 6 (04): 046-051. 